\title{
Artikel
}

\section{De Innovatiewet Strafvordering: meeliften op een hype?}

Prof. mr. M.J. Jacobs*

\section{Inleiding}

In het kader van de modernisering van het Wetboek van Strafvordering werd afgelopen zomer een interessant wetsvoorstel bij de Tweede Kamer ingediend: de 'Innovatiewet Strafvordering'. Deze innovatiewet heeft namelijk als doel om alvast ervaring op te doen met een zestal procedures, bevoegdheden en instrumenten waarvan het de bedoeling is dat die te zijner tijd een plaats krijgen in het nieuwe Wetboek van Strafvordering. Op een na (waarover later meer) staan alle procedures die in de Innovatiewet Strafvordering staan ook in de in 2020 openbaar gemaakte ambtelijke versie van het Wetsvoorstel tot vaststelling van het nieuwe Wetboek van Strafvordering. ${ }^{1}$ Daaruit kan worden afgeleid dat de regering van vijf van de zes procedures al weet dat zij deze onderwerpen in het nieuwe Wetboek van Strafvordering wil opnemen. Het opdoen van ervaring is erop gericht om eventuele 'kinderziektes' in de nieuwe procedures vroegtijdig aan het licht te laten komen en te verhelpen.

Bij verreweg de meeste nieuwe wetten wordt er helemaal niet eerst ervaring opgedaan met de nieuw te regelen onderwerpen; doorgaans bereidt de wetgever een wetsvoorstel voor en pas wanneer dit voorstel tot wet is verheven en in werking is getreden, kan er ervaring wor-

Prof. mr. Rianne Jacobs is bijzonder hoogleraar Wetgeving en reguleringsvraagstukken aan de VU Amsterdam en raadadviseur bij de directie wetgeving en juridische zaken van het Ministerie van Justitie en Veiligheid.

1 Ziewww.rijksoverheid.nl/onderwerpen/nieuwe-wetboek-van-strafvordering/ documenten/publicaties/2020/07/30/ambtelijke-versie-juli-2020wetsvoorstel-wetboek-van-strafvordering. den opgedaan met de nieuwe procedures, bevoegdheden en instrumenten. In dit geval gaat het, als gezegd, echter anders. Binnen het grote project om te komen tot een nieuw Wetboek van Strafvordering verschaft de wetgever zichzelf ook nog eens de mogelijkheid om eerst ervaring op te doen met een aantal onderwerpen waarvan hij denkt dat die uiteindelijk een plaats zouden moeten krijgen in dat nieuwe Wetboek. Dat komt niet zo vaak voor. In het strafprocesrecht is het bij mijn weten nog niet eerder gebeurd, tenzij gefaseerde inwerkingtreding, zoals bij de Wet Terwee in 1993, als experiment wordt beschouwd. ${ }^{2}$

De Innovatiewet Strafvordering kan worden geplaatst in een bredere trend; niet alleen binnen de strafvordering bestaat behoefte aan het opdoen van ervaring met nieuwe onderwerpen of regels, voordat ze 'definitief' ${ }^{3}$ worden ingevoerd, ook daarbuiten is dit de laatste jaren veelvuldig het geval. De behoefte om ervaring op te doen bestaat namelijk op tal van terreinen en er zijn ook tal van verschillende wijzen waarop deze 'uitprobeerfase' wettelijk wordt vormgegeven.

In deze bijdrage zal ik ingaan op de keuzes die de wetgever in het voorstel van de Innovatiewet Strafvordering heeft gemaakt met betrekking tot de 'uitprobeerfase'. Ik zal deze keuzes bespreken in het licht van het fenomeen 'experimenteerregelgeving' zoals opgenomen in de Aanwijzingen voor de regelgeving en waar nuttig afzetten tegen de keuzes die in enkele recente andere (concept)wetsvoorstellen zijn gemaakt bij het vormgeven van de behoefte om ervaring op te doen met nieuw te regelen onderwerpen. Zoals zal blijken zit de innovatie

2 Zie art. VIII, Stb. 1993, 29. Deze wet trad eerst in enkele arrondissementen in werking en pas daarna landelijk.

3 Het woord definitief staat hier tussen aanhalingstekens omdat de meeste wetten niet voor de eeuwigheid gelden; een wet is definitief totdat hij wordt ingetrokken. 
in de Innovatiewet Strafvordering hem niet alleen in de te regelen onderwerpen, maar ook in de vormgeving van het wetsvoorstel zelf.

\section{De vormgeving van de Innovatiewet Strafvordering}

De Innovatiewet Strafvordering behelst een wijziging van het huidige Wetboek van Strafvordering. Er worden zes onderwerpen in opgenomen waarvan de wetgever zich heeft voorgenomen om ze uiteindelijk in het nieuwe Wetboek van Strafvordering op te nemen. De memorie van toelichting geeft de volgende opsomming:

- een voorziening voor de rechter in eerste aanleg of hoger beroep om de Hoge Raad prejudiciële vragen te kunnen stellen in strafzaken;

- voorzien in een regeling dat na inbeslagneming van een geautomatiseerd werk later binnenkomende berichten voor een bepaalde periode kunnen worden onderzocht in het kader van de opsporing;

- het mogelijk maken van een netwerkzoeking na inbeslagneming in het kader van de opsporing;

- de mogelijkheid audiovisuele opnamen onder voorwaarden te kunnen gebruiken als vervanging van een volledig proces-verbaal en daarmee onderdeel te maken van de verslaglegging van bijvoorbeeld verhoren of van de terechtzitting en het erkennen van audiovisuele opnamen als wettig bewijsmiddel;

- de mogelijkheid bieden dat een aantal lichtere opsporingsbevoegdheden waarvan de uitoefening nu aan de officier van justitie is voorbehouden, door de hulpofficier van justitie kunnen worden uitgeoefend, en;

- regelen op welke wijze mediation kan plaatsvinden na aanvang van het onderzoek op de terechtzitting. ${ }^{4}$

Het gaat mij in deze bijdrage niet zozeer om de inhoud van deze zes voorgestelde onderwerpen, maar veeleer om de wijze waarop het wetsvoorstel is vormgegeven. Als bekend wordt het bestaande Wetboek van Strafvordering geheel gemoderniseerd. Aangezien het de bedoeling is dat de onderwerpen uiteindelijk een plaats in het nieuwe Wetboek van Strafvordering krijgen, behelst de Innovatiewet Strafvordering een wijziging van het bestaande, of zo men wil oude, Wetboek van Strafvordering. Wetstechnisch gaat het hier dus niet om een experiment- of experimenteerwet, maar om een gewone wetswijziging.

Uit de memorie van toelichting blijkt dat met het wetsvoorstel wordt beoogd om inzicht te verkrijgen in de gevolgen van de genoemde onderwerpen voor de praktijk,

Kamerstukken II 2020/21, 35869, nr. 3, p. 2. In de consultatieversie van het wetsvoorstel stond nog een zevende voorstel: De mogelijkheid de vordering tot schadevergoeding van de benadeelde partij af te splitsen van het hoofdgeding teneinde deze afzonderlijk te behandelen. Waarom dit voorstel niet is teruggekomen in het ingediende wetsvoorstel, is toegelicht in par. 3.6 van de $M v T$. het beproeven van technieken en instrumenten in het kader van de modernisering om te bezien of zij slagen in hun streven naar verbetering, het kunnen meenemen van de resultaten in het nieuwe Wetboek van Strafvordering. ${ }^{5}$

Het eventueel kunnen aanpassen van het voorstel voor het nieuwe Wetboek van Strafvordering is dus een belangrijke drijfveer voor dit wetsvoorstel. Ook de beantwoording van de vraag of er flankerende maatregelen nodig zijn, zoals aanpassing van werkprocessen, blijkt een doel van het wetsvoorstel te zijn. ${ }^{6}$ Met het oog daarop zijn per onderwerp evaluatiecriteria ontwikkeld en in de toelichting uiteengezet. Dit leidt tot evidence based wetgeving, zo staat te lezen op p. 17 van de toelichting. Deze opmerking over evidence based wetgeving moet uitsluitend worden begrepen in de context van de wettelijke vormgeving van de voorgestelde onderwerpen en dus niet in de keuze van deze zes onderwerpen. Daarover volgt immers uit de toelichting dat het de bedoeling is dat deze onderwerpen een plek krijgen in de het nieuwe Wetboek van Strafvordering. ${ }^{7}$ Van experimenteerwetgeving in de meer klassieke of traditionele zin van het woord, waarbij, zoals de Aanwijzingen voor de regelgeving voorschrijven, in een wet in formele zin een experimenteergrondslag wordt opgenomen, waaraan later met een algemene maatregel van bestuur vorm wordt gegeven, is voor deze onderwerpen dus geen sprake.

\section{De Innovatiewet Strafvordering in relatie tot de Aanwijzingen voor de regelgeving over 'experimen- teerregelgeving'}

De afgelopen jaren is er veel aandacht geweest voor het fenomeen 'experimenteerregelgeving'. Het laatste regeerakkoord stond boordevol voornemens voor experimenten en experimenteerregelgeving, maar ook los daarvan was er al een paar jaar een trend naar meer experimenteerregelgeving te zien. ${ }^{8}$

De term 'experimenteerregelgeving' kan op een scala aan regels zien. Wanneer (wetgevings)juristen spreken over experimenteerregelgeving, dan hebben zij doorgaans het oog op regels die het mogelijk maken om af te wijken van een bestaande regel teneinde te testen hoe de nieuwe regel werkt. In de Aanwijzingen voor de regelgeving is daarover ook een en ander vastgelegd (zie Aanwijzing 2.41 en 2.42). Maar in de praktijk zijn er ook

Kamerstukken II 2020/21, 35869, nr. 3, p. 1-2.

Kamerstukken II 2020/21, 35869, nr. 3, p. 2.

Kamerstukken II 2020/21, 35869, nr. 3, p. 1-2 en p. 17 (waar staat: 'Dit betekent dat we met zekerheid kunnen zeggen dat ten aanzien van de onderdelen van deze innovatiewet het voornemen bestaat om ze deel uit te laten maken van het nieuwe Wetboek van Strafvordering.').

8 M.J. Jacobs, Experimentele wetgeving (oratie Amsterdam VU), Deventer: Wolters Kluwer 2018 (m.n. hfdst.1, par. 2.3.1 en hfdst. 3). 
wetten die regels over experimenteren bevatten, die niet exact volgens de Aanwijzingen voor de regelgeving zijn vormgegeven, maar die toch 'experimenteerregelgeving' worden genoemd. Dit is bijvoorbeeld het geval bij de op 1 juli 2019 in werking getreden Experimenteerwet zelfrijdende auto's. Deze wet regelt een vergunningsplicht voor het mogen testen van zelfrijdende auto's op de openbare weg. ${ }^{9}$

Het voorstel voor de Innovatiewet Strafvordering is in ieder geval géén wet die regels bevat die het mogelijk maakt om tijdelijk af te wijken van een bestaande regel teneinde te testen hoe de nieuwe regel werkt. Het is strikt genomen ook geen wet, zoals de Wet zelfrijdende auto's, die regels bevat over een vergunning om te experimenteren. Het is veeleer een voorstel voor een doodgewone wet die nieuwe regels over nieuwe onderwerpen bevat. Dat die nieuwe regels over die nieuwe onderwerpen eerst een poosje worden gebruikt om te kijken of ze (on)gewijzigd overgenomen kunnen worden in het nieuwe Wetboek van Strafvordering, maakt dat er gesproken kan worden van 'testen' of zo men wil van 'experimenteren'. ${ }^{10}$

De vraag dringt zich op of het mogelijk was geweest om met een of meer 'experimenteerbepaling(en)' als bedoeld in de Aanwijzingen voor de regelgeving te werken. Om te kunnen dienen als 'testmateriaal' voor het nieuwe Wetboek van Strafvordering, hadden dergelijke experimenteerbepalingen logischerwijs ook dan moeten worden opgenomen in het bestaande Wetboek van Strafvordering. Inhoudelijk zou deze keuze echter op verschillende bezwaren zijn gestuit.

Ten eerste zouden experimenteerbepalingen als bedoeld in de Aanwijzingen voor de regelgeving niet voor alle onderwerpen waarmee 'geëxperimenteerd' moet worden, geschikt zijn geweest vanwege de praktische reden dat er voor sommige onderwerpen nog helemaal geen bestaande wettelijke regel in het Wetboek van Strafvordering staat, waarvan afwijking kan worden toegestaan. Dit is bijvoorbeeld het geval met betrekking tot de introductie van de prejudiciële procedure bij de Hoge Raad. Die procedure is nieuw en er is dus geen enkel bestaand artikel in het Wetboek van Strafvordering 'waarvan kan worden afgeweken teneinde te testen hoe de nieuwe regel werkt'.

Ten tweede een principiëler punt. Het Wetboek van Strafvordering leent zich niet goed voor toepassing van experimenteerbepalingen als bedoeld in de Aanwijzingen voor de regelgeving. Artikel 107 Grondwet (codificatieartikel) en artikel 1 Wetboek van Strafvordering (strafvorderlijk legaliteitsbeginsel) brengen met zich dat het strafprocesrecht zo veel mogelijk bij wet in formele zin wordt geregeld vanwege het feit dat de rechten

9 Stb. 2018, 347

10 Naar mijn mening laten ook de adviezen die in het kader van de internetconsultatie van het conceptwetsvoorstel op www.internetconsultatie.nl zijn ingediend zien dat het om een gewoon wetsvoorstel gaat. In deze reacties, maar ook bijv. in het advies van de NVvR (https://nvvr.org/uploads/ documenten/adviezen/667.-Innovatie-Sv.-def.pdf) wordt voornamelijk gereageerd op de (on)wenselijkheid van het opnemen van de voorgestelde onderwerpen in het nieuwe Wetboek van Strafvordering. en vrijheden van burgers bij de strafvordering nu eenmaal vaak in het geding zijn. Delegatie is weliswaar toegestaan, maar aangezien de rechten en vrijheden van burgers al snel in het geding kunnen komen wanneer klassieke experimenteerbepalingen zouden worden ingezet, laten dergelijke experimenten zich niet goed denken. ${ }^{11}$

\section{Methodologie van de experimenten}

Een succesvolle uitvoering van een experiment staat of valt met een solide methodologie. Bij wetenschappelijk onderzoek dient daarvoor aan allerhande voorwaarden, zoals een eenduidige vraagstelling en een weloverwogen onderzoeksopzet, te worden voldaan. Idealiter is hiervan ook bij wetgevingsexperimenten sprake want net als bij ander (wetenschappelijk) onderzoek leidt een gebrekkige onderzoeksvraag of een gebrekkige onderzoeksopzet tot resultaten die niet of niet goed bruikbaar zijn om te bepalen of het experiment succesvol is geweest. Niet voor niets heeft de Afdeling advisering aan dit onderwerp een hoofdstuk gewijd in het advies over de elfde wijziging van de Aanwijzingen voor de regelgeving. ${ }^{12}$

In paragraaf 4 van de memorie van toelichting bij de Innovatiewet Strafvordering wordt ingegaan op de vormgeving van de pilotprojecten en de evaluatiecriteria per project. In zijn algemeenheid wordt aangegeven dat de pilotprojecten die te zijner tijd op basis van de artikelen van de wet uitgevoerd zullen worden, worden geëvalueerd door het WODC, ${ }^{13}$ dat de duur en de inrichting van de pilotprojecten verschillen per onderwerp zodat men, nadat deze pilots zijn afgerond, in het nieuwe Wetboek van Strafvordering wettelijke bepalingen kan opnemen die evidence based zijn. Vervolgens wordt er voor elk van de voorgestelde onderwerpen gemotiveerd wat het oogmerk van het onderzoek is en welke onderwerpen centraal zullen staan bij de evaluatie.

Hoewel de Innovatiewet Strafvordering als gezegd een 'gewone wijzigingswet' is om te onderzoeken of de daarin geregelde onderwerpen ook een plaats zouden moeten krijgen in het nieuwe Wetboek van Strafvordering, sluit paragraaf 4 van de memorie van toelichting vrij goed aan bij de Aanwijzingen voor de regelgeving over experimenteerregelingen en de evaluatie daarvan. Dat

11 Vgl. ook par. 2.3 van het Advies van de Afdeling advisering van de Raad van State van 6 december 2019 inzake de elfde wijziging van de Aanwijzingen voor de regelgeving (No.W01.19.0146/I).

12 Zie hfdst. 2 van het advies.

13 Dit sluit ook aan bij de opvatting van de Afdeling advisering van de Raad van State dat de begeleiding en de beoordeling van het experiment zo veel mogelijk dient te worden belegd bij een wetenschappelijke of een andere onafhankelijke onderzoeksinstantie.Zie p. 17van advies No. W01.19.0146/I. In het advies over de Innovatiewet Strafvordering spreekt de Afdeling (dan ook) waardering uit voor de betrokkenheid van het WODC bij de experimenten, al wordt tevens opgemerkt dat de methodologische verantwoording van het wetsvoorstel verbetering behoeft (zie Kamerstukken II 2020/21, 35869, nr. 4, p. 5). 
moet ook wel want anders dan bij 'echte experimenteerbepalingen' volgt hier niet nog een algemene maatregel van bestuur met bijbehorende toelichting.

Toch zou het niet hebben misstaan als de toelichting nog wat uitvoeriger was geweest. Zo had wat meer duidelijkheid op het punt van het te bereiken resultaat in de rede gelegen; want hoe weten we nu wanneer het doel van de pilots is bereikt? De memorie van toelichting vermeldt zowel dat de voorgestelde onderwerpen een plaats zullen krijgen in het nieuwe wetboek, als dat evaluatie 'kan leiden tot een negatief oordeel' omdat 'uit een pilotproject kan blijken dat de voorgestelde regeling in de praktijk in het geheel niet werkt of belangrijke doestellingen of voorwaarden niet haalt'. ${ }^{14}$ Of een negatieve evaluatie tot schrapping (of niet opnemen ${ }^{15}$ ) van een onderwerp uit het nieuwe Wetboek van Strafvordering zal leiden is niet geheel duidelijk. De memorie van toelichting spreekt over 'bijstelling of aanvulling' van artikelen en 'het nemen van flankerende maatregelen'. Het lijkt de bedoeling dat alle voorgestelde onderwerpen een plaats krijgen in het nieuwe Wetboek van Strafvordering. ${ }^{16}$ Ter relativering kan hier echter aan worden toegevoegd dat ook als er wel wordt gewerkt met klassieke experimenteerbepalingen, lang niet altijd in de toelichting op de bepalingen die een experiment mogelijk maken, duidelijk wordt gemaakt wanneer het doel van het experiment is bereikt. ${ }^{17}$

\section{Evaluatie en werkingsduur van de Innovatiewet}

De Innovatiewet bevat voorts twee andere artikelen die de moeite waard zijn om kort te signaleren: artikel II (evaluatie) en artikel IV (vervaltermijn). Artikel II bevat een evaluatiebepaling zoals die doorgaans in wetten wordt opgenomen: 'De Minister van Justitie en Veiligheid en de Minister voor Rechtsbescherming zenden binnen twee jaar nadat een eerste onderdeel van deze wet in werking is getreden aan beide Kamers van de Staten-Generaal een verslag over de doeltreffendheid en de effecten van deze wet in de praktijk.' Voor echte experimenteerregelingen wordt doorgaans echter een andere bepaling gebruikt, namelijk een bepaling op grond waarvan negen maanden vóór het eind van de werkingsduur van de experimenteerregeling niet alleen een verslag over de doeltreffendheid en de effecten van het experiment in de praktijk aan de beide Kamers der Staten-Generaal moet worden gestuurd, maar ook een standpunt over de vraag of hetgeen waarmee is geëxperimenteerd definitief wordt ingevoerd. Over dat laatste

14 Kamerstukken II 2020/21, 35869, nr. 3, p. 19

15 De uitbreiding van de bevoegdheden van de hulpofficier van justitie is het enige onderwerp dat nog niet in het nieuwe Wetboek van Strafvordering is opgenomen.

16 Kamerstukken II 2020/21, 35869, nr. 3, p. 19

17 Zo bleek mij tijdens het onderzoek dat ik verrichtte ter voorbereiding van mijn oratie in 2018.
- de definitieve invoering van alle onderwerpen uit de Innovatiewet in het nieuwe Wetboek van Strafvordering, inclusief de regeling over de bevoegdheden van de hulpofficier, die nu nog niet in het nieuwe Wetboek van Strafvordering staat - lijkt bij de Innovatiewet Strafvordering geen discussie meer te zijn, maar dat neemt niet weg dat er wel nog een standpunt moet worden ingenomen over de vraag of de voorgestelde regels ongewijzigd naar het nieuwe Wetboek van Strafvordering kunnen worden overgeheveld of dat er eerst nog aanpassingen nodig zijn. Het had mijns inziens dan ook niet misstaan als hierover iets zou zijn bepaald in het evaluatieartikel. Wetstechnisch het opvallendst aan het evaluatieartikel is echter dat er voor de termijn waarbinnen de evaluatie moet plaatsvinden is aangeknoopt bij de inwerkingtreding van 'het eerste onderdeel van deze wet' en niet, zoals bij normale experimenteerregelingen het geval is, bij het moment waarop de experimenteerregeling vervalt. Het is een beetje een technisch verhaal, maar feitelijk werkt deze manier van regelen voor het eerste onderdeel dat in werking treedt (maar als de gehele wet ineens in werking treedt voor alle maatregelen) niet heel anders uit dan wanneer er wel was aangeknoopt bij het moment waarop de experimenteerregeling vervalt. Een jaar voordat deze wet vervalt, moet de evaluatie naar de beide Kamers worden gestuurd. Deze wet vervalt op grond van artikel IV drie jaar na zijn inwerkingtreding of de inwerkingtreding van het eerste onderdeel, dus twee jaar na de inwerkingtreding moet de evaluatie gereed zijn. Blijkens de memorie van toelichting is deze keus gemaakt om ervoor te zorgen dat de resultaten van de pilotprojecten beschikbaar zijn op een moment dat deze nog ten volle kunnen worden betrokken in de behandeling van definitieve bepalingen in het nieuwe Wetboek van Strafvordering. ${ }^{18}$ Voor onderdelen die later in werking treden, betekent deze keus wel dat de 'experimenteerperiode' korter wordt.

Tot slot is ook geregeld hoe het afloopt met de experimenteerbepalingen uit deze Innovatiewet Strafvordering als het nieuwe Wetboek van Strafvordering er wel of niet komt (art. IV). Dit artikel luidt als volgt:

\section{Artikel IV}

1. Titel X van het Vierde boek van het Wetboek van Strafvordering vervalt drie jaar na inwerkingtreding van deze wet of van het onderdeel van deze wet, tenzij voor die datum een voorstel van wet bij de Tweede kamer is ingediend waarbij ten aanzien van Titel $\mathrm{X}$ of van een of meer afdelingen of artikelen daarvan anders wordt bepaald.

2. Indien een voorstel van wet als bedoeld in het eerste lid wordt ingetrokken of indien een van de Kamers van de Staten-Generaal tot het niet-aannemen van het voorstel besluit, vervalt Titel $\mathrm{X}$ van het Vierde Boek van het Wetboek van Strafvordering. 
Kort gezegd volgt uit dit artikel dat het met de experimenteerbepalingen nog alle kanten op kan. In het (tamelijk onwaarschijnlijke) geval dat er geen voorstel voor een nieuw Wetboek van Strafvordering wordt ingediend, vervalt de Innovatiewet drie jaar na de inwerkingtreding. Overigens staat er 'een voorstel van wet (...) waarbij ten aanzien van Titel $\mathrm{X}$ of van een of meer afdelingen of artikelen daarvan anders wordt bepaald'. Strikt genomen staat er dus dat de experimenteerbepalingen vervallen als er binnen drie jaar geen enkel wetsvoorstel is ingediend dat iets bepaalt over (een onderdeel van) Titel $\mathrm{X}$. Dit zou bijvoorbeeld ook een Invoeringswet kunnen zijn.

Wordt er wel binnen drie jaar een wetsvoorstel ingediend, dan zal in dat wetsvoorstel worden geregeld wat er met de experimenteerbepalingen gebeurt. Mocht het ingediende voorstel om wat voor reden dan ook uiteindelijk door de regering worden ingetrokken of door het parlement niet worden aangenomen, dan vervallen de experimenteerbepalingen ook en wel onmiddellijk. Pilots komen dan ten einde. Kennelijk bestaat er geen vrees dat een dergelijke stopzetting consequenties zal hebben voor lopende zaken.

\section{Enkele andere recente experimenteerwetten}

Zoals gezegd in de inleiding kan de Innovatiewet Strafvordering worden geplaatst in een bredere trend. Ook buiten de strafvordering bestaat behoefte aan het opdoen van ervaring met nieuwe onderwerpen of regels, voordat ze 'definitief' worden ingevoerd. In deze paragraaf bespreek ik heel kort enkele andere experimenteerwetten en voornemens daartoe op het terrein van het procesrecht en het strafrecht. Waar mogelijk wordt een vergelijking gemaakt met de voorstellen uit de Innovatiewet Strafvordering.

Net als in het strafprocesrecht bestaat er in het burgerlijk procesrecht en het bestuursprocesrecht behoefte aan experimenteren. Ten behoeve van experimenten op het terrein van het burgerlijk procesrecht is de Tijdelijke Experimentenwet rechtspleging tot stand gebracht (Stb. 2020, 223). In het bestuursprocesrecht is het echter nog niet tot een wetsvoorstel gekomen. ${ }^{19}$ De Tijdelijke experimentenwet rechtspleging lijkt qua vormgeving in niets op de Innovatiewet Strafvordering. De Tijdelijke experimentenwet rechtspleging is namelijk (wel) een klassieke experimentenwet: bij algemene maatregel van bestuur kan 'met het oog op het bevorderen van eenvoudige, snelle, effectieve en de-escalerende geschilbeslechting bij wijze van experiment gedurende een periode van ten hoogste drie jaar' worden afgeweken van een groot aantal artikelen in het Wetboek van Burgerlijke Rechtsvordering, de Wet op de rechterlijke organisatie,

19 Wel stond in de MvT bij de Tijdelijke experimentenwet rechtspleging dat experimenten met de Wet op de rechterlijke organisatie ook betrekking konden hebben op procedures in het strafrecht of bestuursrecht. de procesrechtelijke bepalingen van Boek 1 BW, de Faillissementswet en de daarop gebaseerde lagere regelgeving en ook nog van een groot deel van de Wet op de rechtsbijstand en de Wet griffierechten in burgerlijke zaken.

Naar aanleiding van het advies van de Raad van State is in de wet voorzien in een rechtsgrondslag voor oprichting van een Toetsingscommissie experimenten rechtspleging. ${ }^{20}$ Deze toetsingscommissie, die breed zal worden samengesteld uit leden met een juridische, economische en sociaalwetenschappelijke achtergrond, moet voorstellen voor experimenten gaan toetsen aan de eisen en criteria uit de wet en een nog op te stellen algemene maatregel van bestuur. De oprichting van een toetsingscommissie die vooraf toetst, is nieuw. ${ }^{21}$ De al wat oudere bestaande experimentenwetten (te weten de Experimentenwet onderwijs uit 1970, de Experimentenwet vooropleidingseisen, selectie en collegegeldheffing, uit 2005 en de Tijdelijke experimentenwet stembiljetten en centrale stemopneming uit 2013) kennen niet een dergelijke toetsingscommissie. ${ }^{22}$ De recente Wet experiment gesloten coffeeshopketen (Stb. 2019, 433) kent een Begeleidings- en evaluatiecommissie experiment gesloten coffeeshopketen. Deze commissie heeft tot taak 'het experiment en de uitvoering van de evaluatie te volgen en daarover verslag te doen aan de Ministers'. Dat in de experimenteerregelgeving is geregeld dat bij de evaluatie een (onafhankelijke) commissie een rol speelt, komt echter geregeld in experimenteerregelingen voor. ${ }^{23}$

De experimenten die op grond van de Tijdelijke experimentenwet rechtspleging plaatsvinden, worden thans uitgewerkt. Blijkens de memorie van toelichting kan worden gedacht aan (o.a.) de volgende experimenten: het op informelere wijze, bijvoorbeeld door een eenvoudig formulier aanhangig maken van een procedure, de uitwisseling van informatie en standpunten tussen partijen eenvoudiger laten verlopen, het vereenvoudigen van bewijsverrichtingen, een verruiming van de mogelijkheid in persoon te procederen. ${ }^{24}$

In de Innovatiewet Strafvordering wordt niet gewerkt met een toetsingscommissie die voorstellen voor experimenten vooraf toetst. De Raad van State heeft er in het advies over het voorstel ook met geen woord over gerept. Naar alle waarschijnlijkheid komt dit omdat de onderwerpen van de pilots in de Innovatiewet Strafvordering reeds zijn geregeld. Dat is anders dan bij de Tijdelij-

20 Art. 6 Tijdelijke experimentenwet rechtspleging.

21 Althans bij experimenteerwetgeving als in deze bijdrage bedoeld. Bij medische-wetenschappelijk onderzoek en bij dierproeven is het gebruikelijk dat projectvoorstellen vooraf worden getoetst door een commissie bestaande uit deskundigen.

22 Als enigszins vergelijkbaar zou de rol van de Commissie regionaal overleg luchthaven Schiphol bij experimenten op grond van art. 8.23a Wet luchtvaart kunnen worden genoemd. Dit artikel stelt als eis om te mogen experimenteren dat genoemde commissie 'bij advies heeft aangegeven dat het experiment een gunstig effect kan hebben op de hinderbeleving'. De vergelijkbaarheid zit hem echter uitsluitend in de fase waarin wordt 'geadviseerd', niet in de onafhankelijkheid of deskundigheid van de leden van de commissie.

23 Bijv. art. 13 Besluit experiment instellingsaccreditatie met lichtere opleidingsaccreditatie.

24 Kamerstukken II 2018/19, 35263, nr. 3, p. 21 
ke experimentenwet rechtspleging, die 'slechts' een grondslag geeft voor het regelen van experimenten bij algemene maatregel van bestuur. Bij de Innovatiewet Strafprocesrecht is omwille van het strafvorderlijk legaliteitsbeginsel juist afgezien van een wetsvoorstel dat zich beperkt tot het geven van een experimenteergrondslag. Sterker nog, van twee onderwerpen zegt de Raad van State met zoveel woorden dat het niet om experimenten gaat, maar om voldragen voorstellen die beter van de Innovatiewet Strafvordering zouden kunnen worden afgesplitst en als zelfstandige wetsvoorstellen kunnen worden ingediend.

Voor wat betreft een evaluatie- of begeleidingscommissie bevat de Innovatiewet Strafvordering evenmin een bepaling. Als gezegd wordt in de memorie van toelichting aangegeven dat de pilotprojecten die te zijner tijd op basis van de artikelen van de wet uitgevoerd zullen worden, worden geëvalueerd door het WODC. Dat de wet geen expliciet artikel bevat over wie wat wanneer evalueert, staat er uiteraard niet aan in de weg dat er wordt geëvalueerd en dat die evaluatie zeer zorgvuldig ter hand wordt genomen. Hoewel evaluatie van wetten in veel gevallen relevant kan zijn, moet juist bij experimenteerwetgeving gewaarborgd zijn dat de methodologie vanaf de opzet tot en met de evaluatie zodanig is dat er ook echt geleerd kan worden van het experiment. Dat wil niet zeggen dat alle experimenteerregelingen van precies dezelfde evaluatiebepalingen hoeven te worden voorzien, maar wel dat op zijn minst in de toelichting bij iedere experimenteerregeling inzicht moet worden geboden in hoe het experiment wordt gemonitord en geëvalueerd en wanneer het doel van het experiment is bereikt. Bij de monitoring en evaluatie zal ondersteuning van onafhankelijke deskundigen op het gebied van (wetenschappelijk) onderzoek veelal onontbeerlijk zijn. ${ }^{25}$ Een recente andere experimentenwet op het terrein van het strafrecht is de al genoemde Wet experiment gesloten coffeeshopketen. Net als de Innovatiewet Strafvordering gaat het hier niet om een klassieke experimenteerwet waarbij de wet in formele zin de grondslag biedt om bij algemene maatregel van bestuur af te wijken van de wet. Deze wet maakt het mogelijk dat voor de duur van het experiment (vier jaar, zie art. 4 lid 1 Wet experiment gesloten coffeeshopketen) wordt afgeweken van de bestaande wet- en regelgeving, in die zin 'dat ter zake van de teelt en levering of aanvoer van hennep - in de praktijk wordt dit ook wel aangeduid als de achterdeur en de verkoop daarvan in coffeeshops strafrechtelijke vervolging is uitgesloten, uitsluitend en voor zover die handelingen worden verricht in het kader van het experiment en overeenkomstig de eisen die daaraan bij of krachtens de wet worden gesteld'. ${ }^{26}$ Het doel van dit experiment is blijkens de memorie van toelichting 'om te bezien of en hoe op kwaliteit gecontroleerde hennep of hasjiesj gedecriminaliseerd aan de coffeeshops kan wor-

25 Zie ook het advies van de Raad van State over de elfde wijziging van de Aanwijzingen voor de regelgeving (6 december 2019, No. W01.19.0146/I, p. 16-17).

26 Kamerstukken II 2017/18, 34997, nr. 3, p. 1. den geleverd en daar binnen een gesloten coffeeshopketen kan worden verkocht, alsmede wat de effecten daarvan zijn'. ${ }^{27}$ Heel nadrukkelijk wordt daarbij aangegeven dat niet wordt vooruitgelopen op politieke besluitvorming over de weging van de opgetreden effecten. ${ }^{28}$ Dat heeft ongetwijfeld te maken met de maatschappelijke discussie over de problematiek van de ongereguleerde achterdeur.

Als gezegd is er een Begeleidings- en evaluatiecommissie experiment gesloten coffeeshopketen die het experiment en de uitvoering volgt en daarover verslag doet aan de minister van Justitie en Veiligheid en de minister voor Medische Zorg. In het Besluit experiment gesloten coffeeshopketen worden nadere regels gegeven over het volgen en evalueren van het experiment door de commissie (art. 44 Besluit experiment gesloten coffeeshopketen). De evaluatie en het verslag moeten uiterlijk acht maanden voordat het experiment eindigt aan de ministers worden gestuurd (art. 11 lid 3 Wet experiment gesloten coffeeshopketen). De ministers maken vervolgens een kabinetsstandpunt over het verslag. Daarin moeten zij ook aangeven welke gevolgen zij wensen te verbinden aan het verslag. Ook deze wet kent een vervalbepaling: vier jaar en zes maanden nadat het experiment is gestart vervalt de wet (art. 17 lid 2 Wet experiment gesloten coffeeshopketen).

De voorbereiding van dit experiment is in volle gang. De benodigde wet- en regelgeving is de afgelopen jaren tot stand gebracht, de Begeleidings- en evaluatiecommissie is benoemd, de deelnemende gemeenten zijn bekend en in mei 2021 zijn de eerste telers aangewezen die meedoen aan het experiment. De ministers moeten nog besluiten wanneer de experimenteerfase daadwerkelijk start. Naar verwachting zal dit in de tweede helft van 2022 zijn; het startbesluit zal in de Staatscourant worden medegedeeld. ${ }^{29}$ Vanaf dat moment gelden gedurende de gehele looptijd van het experiment de regels die voor dit experiment tot stand zijn gebracht. ${ }^{30}$ Op het punt van de aanvang en het eind van het experiment is er dus een interessant verschil te zien tussen de Wet experiment gesloten coffeeshopketen en de Innovatiewet Strafvordering. Het experiment in de eerste wet wordt al enige tijd voorbereid, maar het echte startsein moet nog gegeven worden. Vierenhalfjaar na het startsein eindigt in beginsel het experiment en vervalt de Wet experiment gesloten coffeeshopketen. Deze keuze is gemaakt omdat bij het opstellen van het wetsvoorstel al wel duidelijk was dat het experiment veel voorbereiding(stijd) vergde, maar niet hoeveel precies én omdat bepaalde voorbereidingshandelingen die ten behoeve van het experiment moeten plaatsvinden zonder artikel 3 Wet experiment gesloten coffeeshopketen verboden zouden ken II 2021/22, 24707, nr. 484.

Op http://www.rijksoverheid.nl/onderwerpen/experiment-geslotencoffeeshopketen-wietexperiment/tijdlijn-experiment-gesloten-coffeeshopketen is te zien wat er tot nu toe is geregeld en wat er nog moet gebeuren om het experiment mogelijk te maken. 
zijn. De Wet experiment gesloten coffeeshopketen moest dus wel in werking treden (ruim) voordat het daadwerkelijke experiment zou starten. ${ }^{31} \mathrm{Bij}$ de Innovatiewet Strafvordering starten de experimenten zodra de wet of de onderdelen die zien op een bepaald artikel, in werking treden. Kennelijk kan de voorbereiding van de experimenten die op grond van deze wet mogelijk worden gemaakt plaatsvinden zonder dat de wet al in werking is getreden of kunnen de voorbereiding en uitvoering binnen de in artikel IV genoemde periode van drie jaar plaatsvinden.

Afgezien van het feit dat de Wet experiment gesloten coffeeshopketen geen betrekking heeft op procesrecht, valt in vergelijking met de Innovatiewet Strafvordering op dat eerstgenoemde wet 'slechts' één experiment regelt. De Innovatiewet strafvordering regelt er zes. Maar: voor het wietexperiment geldt dan weer - net als voor de uitbreiding van de bevoegdheden van de hulpofficier van justitie in het voorstel voor de Innovatiewet Strafvordering - dat nog open ligt wat er na afloop van het experiment gaat gebeuren.

\section{Tot slot}

De titel van deze bijdrage luidt 'De Innovatiewet Strafvordering: meeliften op een hype?'. Met hype wordt gedoeld op de grote aandacht die er de afgelopen jaren in wetgevingsland is geweest voor experimenteerwetgeving. ${ }^{32}$ Hoewel de citeertitel 'Innovatiewet Strafvordering' de indruk zou kunnen wekken dat ook het strafprocesrecht meelift met de hype rondom experimenteerregelgeving, is daarvan mijns inziens geenszins sprake. Op weloverwogen wijze wordt een (gewone) wijzigingswet gebruikt als vehikel om vooruitlopend op het nieuwe Wetboek van Strafvordering ervaring op te gaan doen met een zestal nieuwe onderwerpen. ${ }^{33}$ De link met de experimenteerwetgeving is er echter ook, doordat er in de toelichting blijk van wordt gegeven dat de opstellers zich rekenschap hebben gegeven van het regeringsbeleid met betrekking tot experimenteerwetgeving. Dat valt positief te waarderen, want daardoor is er in een vroeg stadium al aandacht voor de pilots en de evaluatie. Bij gewone wetten (ook die met een evaluatiebepaling) wordt lang niet altijd al in de fase van het opstellen van het wetsvoorstel inhoudelijk nagedacht over de vraag hoe de wet het best kan worden geëvalueerd. Bo-

31 Kamerstukken II 2017/18, 34997, nr. 3 herdruk, p. 17 en 21.

32 Getuige het grote aantal experimenteervoornemens in het laatste regeer akkoord, het aantal recente wetsvoorstellen dat experimenteerbepalingen bevat en de wijziging van de aanwijzingen 2.41 en 2.42 van de Aanwijzingen voor de regelgeving en het uitvoerige advies daarover van de Afdeling advisering van de Raad van State.

33 Deze aanpak doet denken aan de gefaseerde inwerkingtreding waarvoor is gekozen bij het digitaal procederen. Ook daar werd gesproken van 'experimenteren', hoewel het er niet om ging dat proefondervindelijk werd vastgesteld of bepaalde instrumenten een bijdrage konden leveren aan de oplossing van een maatschappelijk probleem. Men wilde gewoon bewerkstelligen dat kon worden proefgedraaid met het digitale systeem (Jacobs 2018, p. 34-37). vendien is de figuur van het 'testen met voorgenomen regels' ook interessant in het licht van de kwaliteit van regelgeving. Het Integraal afwegingskader voor beleid en regelgeving verplicht ertoe om bij de voorbereiding van wet- en regelgeving de effecten van nieuwe regelgeving voor burgers, bedrijven, de overheid, het milieu, enzovoort in beeld te brengen. Normaliter worden die effecten in beeld gebracht door toetsingsinstanties naar hun visie te vragen en door de internetconsultatie. Het blijft dan echter bij een papieren exercitie. Nieuwe regels 'in real life' testen kan ertoe leiden dat de effecten veel duidelijker kunnen worden waargenomen. ${ }^{34}$ Dat de regels, zo nodig, eenvoudig kunnen worden bijgesteld, draagt bij aan de kwaliteit van de regelgeving en kan onnodige herstelwetgeving voorkomen. In dat licht heb ik getwijfeld over wat ik vond van de opname in de Innovatiewet Strafvordering van de twee onderwerpen die door de Raad van State als 'voldragen wettelijke regelingen' werden gekwalificeerd (de prejudiciële procedure en de bevoegdheden na de inbeslagneming van een geautomatiseerd werk). Enerzijds was ik het eens met de Raad dat deze voorstellen eigenlijk geen experimenten behelzen. Anderzijds begreep ik de behoefte van de regering, gevoed door adviezen uit de strafrechtspraktijk, ${ }^{35}$ aan een mogelijkheid om zo nodig nog aanpassingen te kunnen doorvoeren als daar aanleiding toe bestaat. De opname in de Innovatiewet Strafvordering biedt daartoe de gelegenheid. Het afsplitsen van deze onderwerpen en ze in afzonderlijke wetsvoorstellen bij de Tweede Kamer indienen, zoals de Raad van State adviseerde, had deze mogelijkheid in dit geval ook geboden omdat het immers de bedoeling is deze twee onderwerpen in het nieuwe Wetboek van Strafvordering op te nemen. Daarom heb ik er uiteindelijk toch geen moeite mee dat de twee niet-experimentele onderwerpen in de Innovatiewet Strafvordering zijn opgenomen. Het zou wel duidelijker zijn geweest als in de Innovatiewet Strafvordering beter het onderscheid was onderbouwd tussen de experimenten en de niet-experimenten. De naam Innovatiewet had ook dan de lading nog steeds gedekt.

Een punt dat moet worden onderscheiden van het al dan niet experimentele karakter van de voorstellen, is de wens om regels eenvoudig en snel te kunnen bijstellen als na de inwerkingtreding blijkt dat daaraan behoefte bestaat. Daar zou experimenteerwetgeving naar mijn mening niet voor moeten worden gebruikt, of beter gezegd misbruikt. Helder is dat daaraan in de praktijk soms behoefte is en dat de procedure om een wet te wijzigen dan vaak te lang duurt. Als dat het probleem is, dan moeten we dát probleem proberen op te lossen door na te denken over de gevallen waarin we vinden dat regels sneller moeten kunnen worden aangepast, hoe zich dat verhoudt tot het uitgangspunt dat wetgeving bestendig hoort te zijn en het gesprek aangaan of daar een goede en snellere procedure voor kan worden ontworpen.

Al kan dat 'in real life testen' in bepaalde gevallen misschien ook wel anders, bijvoorbeeld in scenario-experimenten (K. van den Bos, Inleiding empirische rechtswetenschap, Den Haag: Boom juridisch 2021, p. 93-97).

35 Kamerstukken II 2020/21, 35869, nr. 4, p. 7. 